\title{
A Need Analysis Study in Developing Multimedia for Functional Grammar Course
}

\author{
Melia Nesti Ayu' ${ }^{1}$ Hamzah $^{2}$, Refnaldi ${ }^{3}$ \\ \{melianestiayu@gmail.com ${ }^{1}$ \} \\ ${ }^{1}$ Student of English Education of Graduate Program, Universitas Negeri Padang, Padang, \\ Indonesia \\ ${ }^{2,3}$ Lecturer of English Education of Graduate Program, Universitas Negeri Padang, Padang, \\ Indonesia
}

\begin{abstract}
In developing multimedia, the need analysis takes an important role. There are some instructional designs in developing and designing multimedia. Instructional design is usually started by analyzing the students' need. This study aimed to find out the needs of students on multimedia on Functional Grammar Course. The subject of the study was the English Department students who have attended Functional Grammar Course at Universitas Negeri Padang. The sample of the study was selected by using cluster sampling, and Educational 3 class was the sample. The data were collected by using questionnaire. The questionnaire of need analysis contains three components namely necessity, lack, and want. The indicators of the needs analysis questionnaire consist of the necessities on multimedia, lack in the content of functional grammar course, and wants on multimedia. Based on the findings of needs analysis, it showed that the students strongly agreed that the use of multimedia is needed in teaching-learning process. The result of this study will be used as reference in the next study in developing multimedia.
\end{abstract}

Keywords: Need analysis, multimedia, functional grammar.

\section{Introduction}

The success of teaching and learning cannot be separated from the media. It has an important role in supporting teachers to reach the teaching-learning goals. No matter what approach is used in the classroom, it is agreed that media can improve the language teaching. By using media, teachers can emphasize their points of the material while at the same time gain the students' interest to the lesson. In teaching English as a foreign language which the students get minimal exposure to the language outside the classroom, the media is really useful. Media can provide students with the language exposure they need since media help teachers to inspire students by bringing a piece of real life into the classroom and by performing language in its more complete communicative context. In addition, media can also provide a mass information and cultural richness input which is not available in the classroom. One of the most fundamental advantage of using media in the classroom is it can lend authenticity to the classroom circumstances, reinforce for students the direct connection between the language classroom and the outside world. [1] 
Teachers use many kinds of media in their teaching, it can be mechanical; or non mechanical. Almost everything can be used as a media in education. The media itself can be found as pictures, cards, video, realia, puppets, newspaper, brochures, puppets, and online instruction over the internet, etc. By presenting the material by using several media, students may be more active in the class. Besides, they may be more motivated to learn.

Multimedia can be defined as the combination of different content forms. It includes a combination of text, audio, images, animation, video, or interactivity content forms. It is usually recorded and played, displayed, or accessed by information content processing devices, such as computerized and electronic devices, but it can also be a part of a live performance. Multimedia in educational context aims to describe the mix of video and audio cassettes, printed texts and handbooks which traditionally make up distance learning material. [2] Besides, multimedia can be defined as the presentation of words and pictures. [3] The words can be printed text or spoken text. Meanwhile, pictures can be clarified as illustrations, photos, animation, or video. Beside, the multimedia principle states it is better for people to learn from the words and pictures than words alone. It means that students more understand the lesson through the use of multimedia. Furthermore, he states more specifically that it can make people learn more deeply as appropriate pictures are added to text.

The definition of multimedia can be different based on the level. [4] Multimedia can be defined as the use of multiple delivery media such as computers, screens, and loudspeakers on the level of technology. On the level of presentation formats, multimedia means the use of different forms of presentation such as texts and pictures. On the level of sensory modalities, it means the use of multiple senses such as the eye and the ear. Multimedia usually refers to the capacity of computers to provide real-time presentations of nearly all existing media and sensory modes of instruction. [5] Multimedia is also the combination of interactive elements by using computer technology. [6] Multimedia has been associated with technology recently. For example, the existence of CDROM, CD-I (compact disc-interactive) and the World Wide Web irrespective of the material they contain.

Students learn best by seeing the value and importance of the information presented in the classroom. In order to achieve the ultimate goal of student learning it is important to use a combination of teaching methods and to make the classroom environment as stimulating and interactive as possible. Therefore, proper combination of multimedia and teaching methodology is appropriate to attract students' attention towards English language learning.

Nowadays, the development of technology has affected to education. It changes the way lecturers teach. They tend to use laptop than to use whiteboard, marker and other traditional things in presenting the material. Besides, the rapid development of internet makes changes in the way students learn. They just send their assignment to their lecturer through e-mail when they are at home. They do not need paper and pen in making assignment anymore. It really helps the students in learning process. Unfortunately, the multimedia in the functional grammar class does not run well as expected. The preliminary research has been conducted in state University of Padang by interviewing some students which have taken Functional Grammar Class and the students who were attending the class.

Based on the preliminary research, it can be found that the use of multimedia in Functional Grammar class is still limited. The students said that the lecturer present the materials by using presentation format through the Microsoft PowerPoint software. The slide show presentation only consists of the text about the material which is in black and white form. The use of colors, graphics, and other objects, such as audio and video are neglected by lecturers. Besides, they do not use design theme effects or any slide transitions. In short, their slide presentation is very simple. 
Furthermore, multimedia used in functional grammar class is not appropriate yet. In functional grammar class, the material should be presented in diagram form or in table form in order to make student easier to understand the material. In fact, lecturers just present the material in a text form. Besides, the multimedia that made by lecturers do not covers various learning activities for the students. The multimedia made by lecturers is only made for presenting the materials. It does not include the activities for the students. They just do the exercises which are included in their textbook. As a result, they do not have many activities which measure their comprehension about the materials. As it is known that in functional grammar class students are not only taught about the theory, but also its application in analyzing the text or sentences. Therefore, they need many kind activities in order to know whether they understand the lesson or not.

The limited use of multimedia in learning might happen because multimedia that has been made by the lecturers may be not based on the students' needs. Lecturers do not know the students needs of multimedia in studying functional grammar class. As a result, they do not know which multimedia that is appropriate for their students in functional grammar course.

Needs analysis takes an important role in designing English for Academic Purposes (EAP) program. It is conducted to collect the information about the needs of a particular group of students in order to design a suitable curriculum, syllabus, and materials. [7] Needs analysis can be defined as the technique in collecting and assessing information related to course design. [8] Besides, need analysis is the main activity in gathering information incorporates learners' goals and backgrounds, their language proficiencies, their reasons for taking the course, their teaching and learning preferences, and the situations they will need to communicate in. Besides, needs analysis is identifying of specific language needs that can be addressed in developing goals, objectives, and content in language program. [9]

It needs to clarify between target needs and learning needs. The target needs refers to what the learners needs to do in the target situation and the learning need refers to what the learner needs to learn. They categorize target needs into (1) necessities; what the learner has to know in order to function effectively in the target situation (2) lacks; the discrepancy between necessity and what the learner already knows, (3) wants; what the learner actually wants to learn or what they feel they need. The learner's wants may or may not confirm those perceived by the lecturers of course designers. Meanwhile, the learning need is equated to the route of learning. This concerns to the things such as how learners learn the language, why they learn it, what resources are available to help them. [10]

Needs analysis refers to identify what specific language and skills the group of language learners will need.[11] The result of needs analysis is used to determine and refine the content of the course. Besides, it is used to assess learners and learning at the end of the course. The needs analysis process consists of target situation analysis, Discourse analysis, Present situation analysis, Learner factor analysis, and Teaching context analysis. Furthermore, needs analysis as the process which is done to establish the "what" and the "how" of a course.[12] It means that needs analysis is conducted to know the purpose and the content of the course. It is the first stage in ESP course development, followed by curriculum design, materials selection, methodology, assessment, and evaluation.

There are many researches that have been done related to need analysis in developing media in teaching and learning. The first research entitled "A Need Analysis in Developing Virtual Laboratory According to the Chemistry Teachers". This research aimed to find out the need in the chemistry class according to the chemistry teachers. The respondents of this descriptive research were 37 chemistry teachers who have been teaching chemistry for at least 5 years. The 
results of this study obtained $91.89 \%$ of respondents stated that they need an integrated virtual chemistry laboratory in hybrid learning. [13]

The next research entitled 'Needs Analysis in the Development of Natural Science Teachers' Book of Junior High School based on Local Wisdom of West Sumatra" aimed to perform needs analysis in developing natural science teachers' book of junior high school based on local wisdom of West Sumatra. Needs analysis consists of three aspects items, namely teacher analysis, task analysis, and material analysis. The respondents of this descriptive research were natural science teachers at SMP N 18 and SMP N 28 in Padang City. The research instruments used were observation sheet, questionnaire and interview guide. Based on the results of the needs analysis, the teacher needs a natural science teachers' book based on local wisdom for Natural science (IPA) materials. [14]

Those previous researches have similarity and difference with this research. This research similarly focused on the need analysis. On the other hand, this research had different subject compared with previous researches. This research focused on the need analysis on multimedia. Referring to previous researches related to need analysis, there was no one conducting research about the need analysis on multimedia for Functional Grammar Class. Thus, it seems that it was necessary to conduct this research which was never researched before and it was different from the others whether it was about the focus of the research or the students being observed.

In conclusion, needs analysis is a tool in getting the information about the students needs. It can be done by analyzing the target needs and learning needs of the students. The result of the needs analysis can be used as the consideration in developing goals, objectives, and content of the course. Based on the explanation above, it can be concluded that it is important to conduct a research about students' need analysis in order to develop multimedia for Functional Grammar Course.

\section{Method}

The population of the research was English Department students who have attended Functional Grammar Course at $5^{\text {th }}$ semester. The sample of the research was selected by using cluster sampling. There were four classes of education program. Then, Educational 3 class is the sample of this study. Questionnaire was used to obtain the data about students needs on multimedia in Functional Grammar Class. The questionnaire of need analysis examines three components namely necessity, lack, and want. [10] The indicators of the needs analysis questionnaire consist of the content of functional grammar and the multimedia. Questionnaires were distributed to the students. Then, they were asked to fill the questionnaires based on their needs. The data from the questionnaires were analyzed quantitatively by using the following formula, and the result was classified into the following interval as in Table 1.

$$
\text { Percentage }=\frac{\text { Total scores }}{\text { maximum score }} \times 100
$$

Table 1. The category of percentage level of the students.

\begin{tabular}{ll}
\hline Percentage & Category \\
\hline $80-100 \%$ & Strongly agree \\
$60-79.99 \%$ & Agree \\
$40-59.99 \%$ & Undecided \\
$20-39.99 \%$ & Disagree \\
$0-19.99 \%$ & Strongly Disagree \\
\hline
\end{tabular}




\section{Result and Discussion}

The data gotten from the need analysis is divided into three parts, which are necessity, lacks, and wants. The data about the students' necessities on multimedia is described and analyzed as follow:

Table 2. The necessities on multimedia

\begin{tabular}{lcc}
\hline Item & Percentage & Category \\
\hline Text & $89 \%$ & Strongly agree \\
Audio & $86 \%$ & Strongly agree \\
Video & $81 \%$ & Strongly agree \\
Graphic/ & $86.50 \%$ & Strongly agree \\
animation & & \\
Print publications & $84.50 \%$ & Strongly agree \\
Presentation & $86.50 \%$ & Strongly agree \\
Tutorials & $85.50 \%$ & Strongly agree \\
Simulations & $83.50 \%$ & Strongly agree \\
Games & $82 \%$ & Strongly agree \\
Web sites & $77.50 \%$ & Agree
\end{tabular}

Based on the findings, it can be concluded that students strongly agreed that lecturers should use text in teaching Functional Grammar. Besides, the use of graphic/animation and presentation are also media which students strongly agreed. The next media should be used by lecturers is audio $(86 \%)$, followed by tutorials $(85.50 \%)$, print publication $(84.50 \%)$, simulations $(83.50 \%)$, games $(82.50 \%)$, video $(81 \%)$, and web sites $(77.50 \%)$. Based on the score gotten, it can be concluded that various media are needed for students. The next data from questionnaire is the lacks on functional grammar.

Table 3. The lacks on functional grammar

\begin{tabular}{|c|c|c|c|c|c|}
\hline Item & $\begin{array}{l}\text { Percenta } \\
\text { ge }\end{array}$ & $\begin{array}{c}\text { Categor } \\
\mathrm{y}\end{array}$ & Item & $\begin{array}{l}\text { Percenta } \\
\text { ge }\end{array}$ & $\begin{array}{l}\text { Catego } \\
\text { ry }\end{array}$ \\
\hline Process types & $72 \%$ & Agree & $\begin{array}{l}\text { Nominal Group } \\
\text { structure }\end{array}$ & $74.50 \%$ & Agree \\
\hline $\begin{array}{l}\text { Participants } \\
\text { roles }\end{array}$ & $67 \%$ & Agree & $\begin{array}{l}\text { Nominalization } \\
\text { and grammatical } \\
\text { metaphor }\end{array}$ & 75 & Agree \\
\hline $\begin{array}{l}\text { Circumstance } \\
\mathrm{s}\end{array}$ & $68 \%$ & Agree & $\begin{array}{l}\text { Spoken and } \\
\text { written language } \\
\text { and mode }\end{array}$ & $74.50 \%$ & Agree \\
\hline $\begin{array}{l}\text { Mood and } \\
\text { Residue }\end{array}$ & $61 \%$ & Agree & $\begin{array}{l}\text { Spoken and } \\
\text { written language } \\
\text { differences }\end{array}$ & $77 \%$ & Agree \\
\hline $\begin{array}{l}\text { Mood } \\
\text { elements }\end{array}$ & $65.50 \%$ & Agree & Cohesion & $75.50 \%$ & Agree \\
\hline $\begin{array}{l}\text { Types of } \\
\text { mood }\end{array}$ & $69.50 \%$ & Agree & Conjunction & $71.50 \%$ & Agree \\
\hline Modality & $71 \%$ & Agree & $\begin{array}{l}\text { Interpreting } \\
\text { context }\end{array}$ & $73.50 \%$ & Agree \\
\hline
\end{tabular}




\begin{tabular}{|c|c|c|c|c|c|}
\hline $\begin{array}{l}\text { Clause and } \\
\text { Clause } \\
\text { Complex }\end{array}$ & $76.50 \%$ & Agree & $\begin{array}{l}\text { From } \\
\text { lexicogrammatical } \\
\text { analysis to } \\
\text { contextual } \\
\text { description }\end{array}$ & $76.50 \%$ & Agree \\
\hline $\begin{array}{l}\text { Projection and } \\
\text { Expansion }\end{array}$ & $74.50 \%$ & Agree & Texture & $76.50 \%$ & Agree \\
\hline $\begin{array}{l}\text { Theme and } \\
\text { Rheme }\end{array}$ & $66.50 \%$ & Agree & Text structure & $73 \%$ & Agree \\
\hline $\begin{array}{l}\text { Types of } \\
\text { Themes }\end{array}$ & $68 \%$ & Agree & $\begin{array}{l}\text { An exploration of } \\
\text { text types }\end{array}$ & $75.50 \%$ & Agree \\
\hline $\begin{array}{l}\text { Pattern of } \\
\text { Theme } \\
\text { Choice }\end{array}$ & $76.50 \%$ & Agree & & & \\
\hline
\end{tabular}

Based on the data, it can be concluded that students have difficulties in most topics, especially in topic "spoken and written language differences". $77 \%$ of the students agreed that topic about "spoken and written language" is difficult for them. Besides, topic about "Clause and Clause Complex" got $76.50 \%$. Similarly, $76.50 \%$ of students agreed that topics about "Pattern of Theme Choice", from "lexicogrammatical analysis to contextual description", and "Texture" are difficult. In order to help students understand more about the topics, the multimedia should be developed about all topics in Functional Grammar Course.

The last data from questionnaire is about students' wants on multimedia. It is described in the following table.

Table 4. The wants on multimedia.

\begin{tabular}{lcc}
\hline Item & Percentage & Category \\
\hline Text & $84.50 \%$ & Strongly Agree \\
Audio & $85 \%$ & Strongly Agree \\
Video & $79 \%$ & Agree \\
Graphic/ & $82 \%$ & Strongly Agree \\
animation & & \\
Print publications & $81 \%$ & Strongly Agree \\
Presentation & $85 \%$ & Strongly Agree \\
Tutorials & $80 \%$ & Strongly Agree \\
Simulations & $79 \%$ & Agree \\
Games & $77 \%$ & Agree \\
Web sites & $78.50 \%$ & Agree
\end{tabular}

It can be seen from the table that students strongly agreed if lecturers use presentation, text, audio, graphic/animation, print publications, and tutorials in Functional Grammar Course. Based on the result of the students' wants on multimedia, the combination of media can be the best ways in helping students understand the topics of functional grammar.

In the previous researches, need analysis was done to the teachers. [13] Need analysis questionnaire consists of three aspects items, namely teacher analysis, task analysis, and material analysis. [14] On the other hand, this research was done by giving questionnaire to the students. The questionnaire examines the necessities, lacks, and wants. Furthermore, the result of the previous research showed that teacher needs a natural science teachers' book based on 
local wisdom for Natural science (IPA) materials. Similarly, the result of need analysis of the research also showed that students need multimedia in Functional Grammar Course.

\section{Conclusions}

Based on the findings and discussion, it showed that students need multimedia in Functional Grammar course in order to help them understanding the material. The students highly wants lecturers use not only text in learning process, but also the use of the audio, and other multimedia are needed. The result of this study hopefully will be used as a matrix for the next research which is the development multimedia for Functional Grammar Course.

\section{Acknowledgements}

The writer would like to dedicate his deepest gratitude to Dr. Hamzah, M.A., M.M and Dr. Refnaldi, S.Pd, M.Litt who have patiently given the writer a great deal of time, considerable help, great willingness, and suggestions toward the completion of this study. The writer would also like to thank everybody who was important to the success in the realization of this research and to express his apology that he could not mention personally one by one. May Allah bless you all.

\section{References}

[1] B. Donna, "The use of media in language teaching," in Teaching English as a second or Foreign Languange, Marianne Celce-Murcia, Ed. Boston: Nelson Education, Ltd, 2002.

[2] J. Collins, H. Michael, and W. J.J, Teaching and Learning with Multimedia. New York: Routledge, 1997.

[3] R. E. Mayer, Multimedia Learning. UK: Cambridge University Press, 2001.

[4] S. Wolfgang, "An Integrated Model of Text and Picture Comprehension," in The Cambridge Handbook of Multimedia Learning, R. E. Mayer, Ed. Cambridge: Cambridge University Press, 2005.

[5] R. E. Clark and D. F. Feldon, "Five Common but Unquestionable Principles of Multimedia Learning.," in The Cambridge Handbook of Multimedia Learning, R. E. Mayer, Ed. Cambridge: Cambridge University Press, 2005.

[6] Solomon, Introduction to Multimedia. California: McGraw-Hill, 2011.

[7] T. and M. S. J. Dudley-Evans, Development in English for specific Purposes: A Multidisciplinary Approach. Cambridge: Cambridge University Press, 1998.

[8] K. Hyland, English For Academic Purposes: An Advanced Resource Book. New York: Routledge, 2006.

[9] R. C. Richey, J. D. Klein, and M. W. Tracey, The Instructional Design Knowledge Base. New York: Routledge, 2011.

[10] T. Hutchinson and A. Waters, English for Specific Purposes: A Learning-Centered Approach. Cambridge: Cambridge University Press, 2008.

[11] H. Basturkmen, Developing Courses in English for specific purposes. London: London: Palgrave Macmillan, 2010.

[12] L. Flowerdew, "Needs Analysis and Curriculum Development in ESP," in The Handbook of English for Specific Purposes, 1st ed., B. Paltridge and S. Starfield, Eds. West Sussex: John Wiley \& Sons, Inc, 2013.

[13] F. Solikhin, J. Ikhsan, and K. H. Sugiyarto, "A Need Analysis in Developing Virtual 
Laboratory according to the Chemistry Teachers," J. Phys. Conf. Ser., vol. 1156, no. 1, 2019.

[14] F. R. Sari and Usmeldi, "Needs Analysis in the Development of Natural Science Teachers 'Book of Junior High School based on Local Wisdom of West Sumatra," J. Phys. Conf. Ser., vol. 1185, no. 1, 2019. 